\title{
ТИПОВА НАВЧАЛЬНА ПРОГРАМА ІЗ ДИСЦИПЛІНИ “МЕДИЧНЕ ПРАВО УКРАЇНИ" ДЛЯ СТУДЕНТІВ ВИЩИХ ЮРИДИЧНИХ НАВЧАЛЬНИХ ЗАКЛАДІВ
}

\author{
Л. Я. Ковальчук, О. Л. Ковальчук, А. Д. Беденюк, М. В. Чорненький, \\ Т. В. Романюк \\ ДВНЗ “Тернопільський державний медичний університет імені I. Я. Горбачевського”

\section{THE TYPICAL TRAINING PROGRAM OF THE DISCIPLINE "MEDICAL LAW IN UKRAINE" FOR STUDENTS OF LAW UNIVERSITIES} \\ L. Ya. Kovalchuk, O. L. Kovalchuk, A. D. Bedeniuk, M. V. Chornenkyi, T. V. Romaniuk \\ SHEI "Ternopil State Medical University by I. Ya. Horbachevsky"
}

\begin{abstract}
Стаття розкривас основні положення Типових навчальних програм з медичного права України для студентів вищих навчальних закладів III-IV рівня акредитації, що навчаються за напрямом підготовки “Правознавство” і здобувають освітньо-кваліфікаційні рівні “магістр" та “спеціаліст".

This article focuses on the most important provisions of the Standard educational programs on medical law of Ukraine for students of universities of III-IV accreditation level, enrolled in the direction of "Law" and acquire educational qualification level "master" and "specialist".
\end{abstract}

Вступ. Сьогодні в Україні вже сформувалася нова галузь права “Медичне право України” з усіма своїми ознаками галузі права. Чітко окреслені специфічні суспільні відносини (предмет), що регулюються медичним правом, та способи їх правового регулювання (методи) $[1,2]$. I це не дивно, оскільки в системі права будь-якої цивілізованої держави медичне право як специфічний міжгалузевий правовий інститут, котрий об'єднує однорідні норми різних галузей права, посідає особливе місце [3].

Одночасно із розвитком медичного права як галузі права в Україні постає питання необхідності вивчення медичного права як навчальної дисципліни в процесі підготовки як сучасного правознавця, так i лікаря [1-8]. Одним із найважливіших етапів впровадження цієї навчальної дисципліни в курс навчання студентів вищих юридичних навчальних закладів стало затвердження 1 липня 2011 року Міністерством освіти і науки, молоді та спорту України за погодженням із Міністерством охорони здоров’я України та Міністерством юстиції України Типових навчальних програм з медичного права України для студентів вищих навчальних закладів III-IV рівня акредитації, що навчаються за напрямом підготовки "Правознав- ство” і здобувають освітньо-кваліфікаційні рівні "магістр" та "спеціаліст" [7,8].

Як зазначають автори програм, актуальність вивчення проблем медичного права України юристами зумовлена багатьма чинниками. По-перше, блага, які $\epsilon$ предметом регулювання медичного права, - життя та здоров'я людини - $є$ найвищими соціальними цінностями. По-друге, це - правовий нігілізм суб'єктів медичних правовідносин. По-третє, провадження медичної практики має численні притаманні лише їй особливості, на які слід закцентувати увагу на додипломному рівні. По-четверте, має значення праволюдинний компонент медичної сфери, що проявляється у необхідності застосування належних правозахисних та правозастосовних механізмів. По-п'яте, законодавче забезпечення галузі охорони здоров'я дуже об'ємне та різностороннє. По-шосте, необхідним є перехід від господарницького підходу в роботі юриста до гуманістичного, котрий має місце у сфері охорони здоров'я. І нарешті, по-сьоме, аналіз статистики юридичної практики свідчить, що при загальній перевантаженості судів кількість медичних справ незначна.

Основна частина. Відповідно до затверджених типових програм метою вивчення дисципліни "Медичне право України” є комплексна підготовка прав- 
ників з метою формування і розвитку їх професійної компетенції у галузі медичного права, спрямована на отримання необхідного обсягу теоретичних медикоправових знань, набуття практичних навиків спеціалізованого правозахисту й правозастосування, оволодіння достатнім рівнем правової культури і правосвідомості для збереження балансу взаємин між суб'єктами медичних правовідносин і дотримання прав людини у сфері охорони здоров'я.

Завданнями вивчення дисципліни є:

- ознайомити правників із міжнародно-правовими стандартами в галузі прав людини та охорони здоров'я;

- розкрити національне законодавче забезпечення сфери охорони здоров'я, у тому числі надання медичної допомоги;

- висвітлити правовий статус суб'єктів медичних правовідносин;

- з'ясувати форми, способи і засоби захисту прав суб'єктів медичних правовідносин;

- окреслити правові умови і підстави здійснення окремих видів медичної діяльності;

- охарактеризувати види юридичної відповідальності в царині охорони здоров'я.
Викладання курсу "Медичне право” покладатиметься на осіб з вищою юридичною освітою, які мають науковий ступінь кандидата наук або доктора наук і вчене звання, з професійною дослідницькою орієнтацією на медичному праві. Бажаною є наявність другої вищої освіти - медичної.

Дисципліна "Медичне право України” вивчатиметься студентами вищих юридичних навчальних закладів на п’ятому курсі протягом семестру. План навчального процесу для її вивчення включає 54 години навчальних занять. 3 них - 20 годин лекцій, 12 годин практичних занять та 22 години самостійної роботи. Дисципліна вивчатиметься із застосуванням кредитно-модульної системи організації навчального процесу, що запроваджується з метою удосконалення контролю якості знань студентів, сприяння формуванню їх комплексності, забезпечення систематичної самостійної роботи впродовж семестру, підвищення об' єктивності оцінювання знань та адаптації до вимог, визначених Свропейською системою залікових кредитів ECST; і складається із двох змістових модулів. Перший змістовий модуль становлять теми $1-7$, другий - теми 8 - 16. Тематичний план дисципліни наведений в таблиці 1.

Таблиця 1. Тематичний план дисципліни “Медичне право України”

\begin{tabular}{|c|c|c|c|c|}
\hline \multirow[b]{2}{*}{ № } & \multirow[b]{2}{*}{ Назва теми } & \multicolumn{3}{|c|}{ Кількість годин } \\
\hline & & лекції & практичні & $\begin{array}{c}\text { самостійна } \\
\text { робота студента }\end{array}$ \\
\hline \multicolumn{5}{|c|}{$\begin{array}{c}\text { Змістовий модУЛЬ І } \\
\text { МЕДИЧНЕ ПРАВО ЯК ПРАВОВЕ УТВОРЕННЯ }\end{array}$} \\
\hline 1 & $\begin{array}{l}\text { Медичне право і його місце в системах права і } \\
\text { законодавства України. Законодавче забезпечення } \\
\text { охорони здоров'я в Україні: історико-правовий огляд, } \\
\text { сучасний стан і перспективи розвитку }\end{array}$ & 2 & - & 2 \\
\hline 2 & $\begin{array}{l}\text { Основи господарської діяльності та страхування у } \\
\text { сфері охорони здоров'я в Україні. Правова природа } \\
\text { медичної допомоги та медичної послуги }\end{array}$ & 2 & - & 2 \\
\hline 3 & $\begin{array}{l}\text { Система прав людини у сфері охорони здоров’я. } \\
\text { Особисті немайнові права людини у сфері охорони } \\
\text { здоров’я }\end{array}$ & - & 2 & 2 \\
\hline 4 & Правовий статус суб’єктів медичних правовідносин & 2 & 2 & - \\
\hline 5 & $\begin{array}{l}\text { Процедури і механізми захисту прав суб’єктів } \\
\text { медичних правовідносин. Юридична відповідальність } \\
\text { у сфері охорони здоров’я }\end{array}$ & 2 & 2 & - \\
\hline 6 & $\begin{array}{l}\text { Правове регулювання експертної діяльності у сфері } \\
\text { охорони здоров’я в Україні. Дефекти надання } \\
\text { медичної допомоги: юридична оцінка }\end{array}$ & 2 & 2 & - \\
\hline \multirow[t]{2}{*}{7} & $\begin{array}{l}\text { Порівняльне медичне право. Міжнародне медичне } \\
\text { право }\end{array}$ & - & - & 2 \\
\hline & Модульна контрольна робота 1 & - & 1 & - \\
\hline \multicolumn{5}{|c|}{$\begin{array}{c}\text { ЗмістовиЙ модУЛЬ II } \\
\text { СПЕЦІАЛЬНІ ІНСТИТУТИ МЕДИЧНОГО ПРАВА }\end{array}$} \\
\hline 8 & Правове регулювання сімейної медицини в Україні & - & - & 2 \\
\hline
\end{tabular}


Продовження табл. 1

\begin{tabular}{|c|c|c|c|c|}
\hline \multirow[b]{2}{*}{ № } & \multirow[b]{2}{*}{ Назва теми } & \multicolumn{3}{|c|}{ Кількість годин } \\
\hline & & лекції & практичні & $\begin{array}{c}\text { самостійна } \\
\text { робота студента }\end{array}$ \\
\hline 9 & $\begin{array}{c}\text { Правове забезпечення репродуктивного здоров’я і } \\
\text { репродуктивних технологій в Україні. Донорство за } \\
\text { законодавством України } \\
\end{array}$ & 2 & 2 & - \\
\hline 10 & $\begin{array}{c}\text { Законодавче забезпечення профілактики та лікування } \\
\text { інфекційних хвороб, у тому числі тих, що передаються } \\
\text { статевим шляхом }\end{array}$ & 2 & - & 2 \\
\hline 11 & $\begin{array}{c}\text { Правове регулювання провадження фармацевтичної } \\
\text { діяльності та забезпечення населення лікарськими } \\
\text { засобами і виробами медичного призначення в Україні. } \\
\text { Інтелектуальна власність у галузі охорони здоров'я }\end{array}$ & 2 & - & 2 \\
\hline 12 & $\begin{array}{c}\text { Правове регулювання проведення медико-біологічних } \\
\text { експериментів на людях в Україні }\end{array}$ & 2 & - & - \\
\hline 13 & $\begin{array}{c}\text { Народна медицина (цілительство) за законодавством } \\
\text { України }\end{array}$ & - & - & 2 \\
\hline 14 & $\begin{array}{c}\text { Законодавче забезпечення паліативної і хоспісної } \\
\text { медичної допомоги в Україні. Правове регулювання } \\
\text { надання медичної допомоги фізично та соціально } \\
\text { уразливим верствам населення. Правове регулювання } \\
\text { надання психіатричної допомоги в Україні } \\
\end{array}$ & 2 & - & 2 \\
\hline 15 & $\begin{array}{c}\text { Правова регламентація косметології та спортивно- } \\
\text { оздоровчої діяльності (спортивної медицини). } \\
\text { Санаторно-курортна справа. Медичний туризм }\end{array}$ & - & - & 2 \\
\hline 16 & $\begin{array}{c}\text { Правове забезпечення санітарного та епідемічного } \\
\text { благополуччя в Україні }\end{array}$ & - & - & 2 \\
\hline & Модульна контрольна робота 2 & - & 1 & - \\
\hline & Всього 54 години, 3 них: & 20 & 12 & 22 \\
\hline
\end{tabular}

Аудиторне викладання курсу проводиться у вигляді лекцій та практичних занять 3 використанням інтерактивних методик. Із найважливіших тем курсу проводяться семінарські заняття, де можуть бути використані різні форми та методи контролю знань студентів: доповіді, експрес-опитування, доповнення, відповіді, вільна дискусія, співбесіда, обговорення рефератних повідомлень, розв' язання казусів, виконання самостійних та контрольних робіт, індивідуальні завдання тощо. Рівень знань, підготовленості, ерудиції, активності студентів оцінюється викладачем самостійно. Аудиторний курс передбачає не лише доктринальне наповнення, а й закріплення теоретичних знань і напрацювання практичних навиків.

Крім того, передбачено самостійну роботу студентів над теоретичним матеріалом. На самостійне вивчення у позааудиторний час плануються теми, котрі не охоплені навчальним процесом, але передбачені робочою програмою та мають істотне значення для підготовки фахівця-юриста.

Типові навчальні програми регламентують структуру та зміст дисципліни, містять план лекцій та практичних занять, перелік рекомендованої літератури, орієнтовний перелік питань на залік, перелік необхідних для опрацювання нормативних актів.

Формою семестрового контролю є залік у формі співбесіди або письмовій формі. До заліку допускаються ті студенти, які відпрацювали всі пропущені заняття, виправили незадовільні оцінки, отримані на практичних заняттях, набрали мінімальну кількість балів і успішно здали змістові модулі. На залік виносяться ключові питання, ситуативні задачі, що потребують творчої відповіді, аналітичних навиків, вміння синтезувати отримані знання і застосовувати їх при вирішенні практичних завдань.

Оцінювання студентів проводиться за 100-бальною системою шляхом виконання індивідуальних завдань, що включають два поточні змістові модулі (0 - 40 балів), підсумковий (0 - 60 балів) та семестровий контроль (сумарно 0 - 100 балів), що відображено в таблиці 2. Програмами передбачені орієнтовні форми контролю знань на семінарських заняттях та їх оцінка:

- доповідь (виступ на задану тему) - до 5 балів;

- доповнення доповіді - до 3 балів;

- вирішення задачі - до 5 балів;

- експрес-опитування - до 3 балів; 
Таблиця 2. Оцінювання знань студентів

\begin{tabular}{|l|l|}
\hline \multicolumn{1}{|c|}{ Параметри } & \multicolumn{1}{c|}{ Оцінка в балах } \\
\hline Змістовий модуль 1 & $0-20$ \\
\hline Змістовий модуль 2 & $0-20$ \\
\hline Комплексна підсумкова контрольна & $0-60$ \\
\hline Разом (підсумкова оцінка) & $0-100$ \\
\hline
\end{tabular}

- колоквіум - до 5 балів;

- самостійна робота - до 4 балів;

- домашня робота - до 5 балів;

- есе (короткі відповіді на запитання) - до 3 балів;

- тестування (з набору суджень вибрати правильні)

- до 5 балів;

- реферат (змістовна письмова робота на задану тему з аналізом літератури та висновками) - до 5 балів;
- участь у дискусії - до 2 балів;

- підсумкова контрольна робота - до 5 балів;

- мінімальний бал за семінар - 1 бал.

Таким чином, за дану дисципліну студентом може бути отримано максимально 100 балів. Знання студента відображаються у заліковій книжці за чотирибальною (національною) шкалою оцінювання, котра наведена в таблиці 3.

Таблиця 3. Шкала оцінювання

\begin{tabular}{|l|l|l|}
\hline \multicolumn{1}{|c|}{ За 100-бальною шкалою } & \multicolumn{2}{|c|}{ Оцінка за національною шкалою та шкалою університету } \\
\hline $90-100$ & відмінно & 5 \\
\hline $75-89$ & добре & 4 \\
\hline $60-74$ & задовільно & 3 \\
\hline $0-59$ & незадовільно & 2 \\
\hline
\end{tabular}

У результаті закінчення курсу студент повинен знати:

- міжнародно-правові стандарти в галузі прав людини та охорони здоров'я;

- чинне законодавство України про охорону здоров'я, у тому числі біоетичне;

- тенденції нормотворення й державної політики у сфері охорони здоров'я;

- понятійно-категоріальний апарат у галузі медичного права;

- рівні соціального регулювання медичної діяльності;

- права й обов'язки суб'єктів медичних правовідносин;

- механізми й процедури захисту прав людини у сфері охорони здоров'я (національні й міжнародні);

- види й підстави юридичної відповідальності у сфері охорони здоров'я;

- юридичну практику в галузі медичного права, в тому числі Європейського суду з прав людини;

- правові умови провадження окремих видів медичної діяльності.

Студент повинен уміти:

- самостійно працювати із законодавством України та міжнародними стандартами у сфері охорони здоров'я;

- аналізувати правову природу прав людини у сфері охорони здоров'я;

- готувати необхідні процесуальні документи для захисту прав людини у сфері охорони здоров’я;
- застосовувати юридичну практику для правозахисної і правозастосовної діяльності, в тому числі правові позиції Європейського суду з прав людини, Верховного Суду України;

- ефективно використовувати арсенал експертиз для провадження медичних справ;

- належно забезпечувати документообіг у закладі охорони здоров'я;

- використовувати юрисдикційні й неюрисдикційні форми захисту прав людини у сфері охорони здоров'я;

- правильно кваліфікувати наслідки професійної діяльності медичних і фармацевтичних працівників та давати їм належну юридичну оцінку.

Висновки. Затвердження Міністерством освіти i науки, молоді та спорту України Типових навчальних програм з медичного права України для студентів вищих навчальних закладів III-IV рівня акредитації, що навчаються за напрямом підготовки "Правознавство” і здобувають освітньо-кваліфікаційні рівні "магістр" та "спеціаліст”, є значним досягненням у процесі впровадження цієї навчальної дисципліни в курс навчання студентів вищих юридичних навчальних закладів та становлення й розвитку медичного права України загалом.

3 метою систематизації та забезпечення достатніх знань юридичних норм, що регулюють медичні відносини, молодими спеціалістами, котрі закінчують вищі 
медичні навчальні заклади, підвищення їхньої правової культури та свідомості вкрай необхідним сьогодні є вивчення курсу "Медичне право” також у вищих медичних навчальних закладах. Необхідно сприяти

\section{Лiтература}

1. Стеценко С. Г. Медичне право України / С. Г. Стеценко, В. Ю. Стеценко, І. Я. Сенюта. - Київ : Правова єдність, 2008. $-508 \mathrm{c}$.

2. Ковальчук Л. Я. Навчальна дисципліна “Медичне право” як невід'ємна складова підготовки лікаря в сучасних умовах в Україні / Л. Я. Ковальчук, А. Д. Беденюк, М. В. Чорненький // Медична освіта. - 2011. - № 3. - С. $12-14$.

3. Федорчук Є. Медичне право як навчальна дисципліна в світлі Болонської системи/ Є. Федорчук, Н. Козань, С. Федорчук // Медичне право. - 2008.-№. 1.-С. 74- 78.

4. Резолюція учасників V Всеукраїнської науково-практичної конференції з медичного права "Медичне право України : законодавче забезпечення царини охорони здоров'я (генезис, міжнародні стандарти, тенденції розвитку й удосконалення)" (19-21 травня 2011 р., м. Одеса). -Одеса, 2011. $-4 \mathrm{c}$.

5. Про затвердження Міжгалузевої комплексної програми “'Здоров’ я нації” на 2002 - 2011 роки : Постанова Кабі- розвитку на медичних факультетах кафедр медичного права, підготовці відповідних фахівців у цій галузі, розвивати наукову та навчально-методичну роботу з проблематики медичного права.

нету Міністрів України № 14 від 10 січня 2002 року // Офіційний вісник України. - 2002. - № 9. - С. 30.

6. Вдосконалення навчально-освітнього компонента медико-правового забезпечення охорони здоров'я в Україні / В. Ф. Москаленко, Т. С. Грузєва, М. О. Винницька [та ін.] // Сучасні проблеми здоров'я та охорони здоров'я населення. -2008 . - № 4. - С. $81-84$.

7. Медичне право України : типова навчальна програма для студентів вищих навчальних закладів III-IV рівня акредитації, що навчаються за напрямом підготовки "Правознавство” і здобувають освітньо-кваліфікаційний рівень “магістр"/ за ред. В. М. Бронової, І. Я. Сенюти. - К., 2011.$99 \mathrm{c}$.

8. Медичне право України : типова навчальна програма для студентів вищих навчальних закладів III-IV рівня акредитації, що навчаються за напрямом підготовки “Правознавство" і здобувають освітньо-кваліфікаційний рівень “спеціаліст” / за ред. В. М. Бронової, І. Я. Сенюти. -К., 2011. $-96 \mathrm{c}$. 